\title{
Dynamic Regulation of RGS2 Suggests a Novel Mechanism in G-Protein Signaling and Neuronal Plasticity
}

\author{
Tatsuya Ingi, ${ }^{1}$ Andrejs M. Krumins, ${ }^{3}$ Peter Chidiac, ${ }^{3}$ Greg M. Brothers, ${ }^{4}$ Stephen Chung, ${ }^{4}$ Bryan E. Snow, ${ }^{4}$ \\ Carol A. Barnes, ${ }^{5}$ Anthony A. Lanahan, ${ }^{1}$ David P. Siderovski, ${ }^{4}$ Elliott M. Ross, ${ }^{3}$ Alfred G. Gilman, ${ }^{3}$ and \\ Paul F. Worley 1,2 \\ Departments of ${ }^{1}$ Neuroscience and ${ }^{2}$ Neurology, Johns Hopkins University School of Medicine, Baltimore, Maryland \\ 21210, ${ }^{3}$ Department of Pharmacology, University of Texas Southwestern Medical Center, Dallas, Texas 75235, \\ ${ }^{4}$ Quantitative Biology Laboratory, Amgen Institute, Toronto, Ontario M5G 2C1, Canada, and ${ }^{5}$ Department of Psychology \\ and Neurology and Division of Neuronal Systems, Memory, and Aging, University of Arizona, Tucson, Arizona 84724
}

Long-term neuronal plasticity is known to be dependent on rapid de novo synthesis of mRNA and protein, and recent studies provide insight into the molecules involved in this response. Here, we demonstrate that mRNA encoding a member of the regulator of G-protein signaling (RGS) family, RGS2, is rapidly induced in neurons of the hippocampus, cortex, and striatum in response to stimuli that evoke plasticity. Although several members of the RGS family are expressed in brain with discrete neuronal localizations, RGS2 appears unique in that its expression is dynamically responsive to neuronal activity. In biochemical assays, RGS2 stimulates the GTPase activity of the $\alpha$ subunit of $\mathrm{G}_{\mathrm{q}}$ and $\mathrm{G}_{\mathrm{i}} 1$. The effect on $\mathrm{G}_{\mathrm{i}} 1$ was observed only after reconstitution of the protein in phospholipid vesicles containing M2 muscarinic acetylcholine receptors. RGS2 also inhibits both $G_{q^{-}}$and $G_{i}$-dependent responses in transfected cells. These studies suggest a novel mechanism linking neuronal activity and signal transduction.

Key words: RGS; immediate early genes; seizure; neuronal plasticity; G-protein; GTPase-activating proteins; MAP kinase
Neurons respond to extracellular stimuli using both rapid phosphorylation-dependent and transcription-dependent mechanisms. These mechanisms collectively underlie activitydependent neuronal plasticity (Shatz, 1990). Physiological studies support the notion that phosphorylation evokes changes in neuronal properties that can last minutes to hours, although macromolecular synthesis is required to produce changes lasting days to the life of the organism (Flexner et al., 1963; Agranoff, 1981; Goelet et al., 1986; Nguyen et al., 1994). To examine molecules involved in the establishment of transcription-dependent neuronal plasticity, we have cloned and characterized genes that are rapidly induced in neurons of the hippocampus by neuronal activity. Currently, we understand this set of genes to include transcription factors, such as c-fos, c-jun, and zif268 (Morgan et al., 1987; Saffen et al., 1988), as well as proteins that may directly modify cellular and synaptic function. The latter class of proteins are particularly interesting, because their contribution to plasticity can, in principle, be understood by examining their direct biochemical and cellular properties. Examples include the inducible form of cyclooxygenase (Yamagata et al., 1993), a novel cytoskeleton-associated protein (Arc) (Lyford et al., 1995), and a

\footnotetext{
Received April 7, 1998; revised July 6, 1998; accepted July 8, 1998.

This work is supported by National Institutes of Health Grants MH01152 (P.F.W.), MH53608 (P.F.W.), GM34497, and GM30355, a grant from the National Alliance for Research on Schizophrenia and Depression (P.F.W.), Carol A. Barnes Grant AG09219, the Raymond and Ellen Willie Distinguished Chair and Molecular Neuropharmacology Award (A.G.G.), and Robert A. Welch Foundation Grant I-0982 (E.M.R.). We thank M. Papapavlou for excellent technical assistance, and R. Kim for help in studies of RGS subtypes in the brain. We thank Dr. Yaping Tu for providing M2 mAChR-Gi vesicles and assistance with the protocol.

Correspondence should be addressed to Dr. Paul F. Worley, Department of Neuroscience, Johns Hopkins University School of Medicine, 725 North Wolfe Street, Baltimore, MD 21205.

Copyright (C) 1998 Society for Neuroscience $\quad 0270-6474 / 98 / 187178-11 \$ 05.00 / 0$
}

protein that selectively binds metabotropic glutamate receptors (Homer) (Brakeman et al., 1997). These proteins are rapidly induced in neurons and interact with constitutively expressed cellular and synaptic proteins to modify neuronal properties.

In the present study, we report that a member of the regulators of the G-protein signaling (RGS) family (Dohlman and Thorner, 1997; Koelle, 1997), RGS2, is rapidly and selectively upregulated in brain neurons in response to plasticity-inducing synaptic stimuli. Heterotrimeric GTP binding or G-proteins transduce a vast array of receptor-initiated signals into appropriate cellular responses (Gilman, 1987; Hamm and Gilchrist, 1996; Neer and Smith, 1996). The intensity and duration of the response is known to be regulated at the level of the receptor by mechanisms that include agonist-dependent phosphorylation of the receptor and subsequent receptor inactivation and turnover. G-protein function is also critical to signal regulation. In their inactive conformation, G-proteins are heterotrimers that contain GDP-bound $\alpha$, $\beta$, and $\gamma$ subunits. G-protein activation is initiated on agonist binding to the receptor, which elicits a conformational change that is transmitted to the G-protein and causes the $\mathrm{G} \alpha$ subunit to release GDP. Subsequent binding of GTP results in dissociation of GTP- $\alpha$ from $\beta \gamma$, and each of these separated G-protein components can regulate downstream effectors. Signaling is terminated when the $\mathrm{G} \alpha$ subunit, which possesses intrinsic GTPase activity, hydrolyzes GTP and returns to the GDP-bound state. G $\alpha$ then reassociates with $G \beta \gamma$ to reform inactive heterotrimers.

Recently, a novel gene family has been identified that functions to accelerate the rate of intrinsic GTP hydrolysis by $\mathrm{G} \alpha$ and thereby reduce the duration of G-protein activation (Dohlman and Thorner, 1997; Koelle, 1997; Berman and Gilman, 1998). Studies in yeast first identified a gene, termed SST2, that is critical for desensitization of mating pheromone responses (Chan and 
Otte, 1982a,b). SST2 loss-of-function mutants respond to concentrations of pheromone that are 100-fold lower than those required to elicit a response in wild-type cells (supersensitivity). Moreover, wild-type yeast desensitizes to pheromone after $\sim 2 \mathrm{hr}$ of continuous exposure, whereas SST2 mutants do not desensitize. SST2 defined a novel gene and the first member of the RGS family (Dietzel and Kurjan, 1987). Another RGS gene, termed EGL-10, was identified in Caenorhabditis elegans and as a regulator of serotonin-stimulated egg laying (Koelle and Horvitz, 1996). Homologs of SST2 and EGL-10 were identified in mammals and comprise a family of RGS proteins (Druey et al., 1996; Koelle and Horvitz, 1996; Siderovski et al., 1996) that accelerate the intrinsic GTPase activities of $\alpha$ subunits of heterotrimeric G-protein (Berman et al., 1996; Chen et al., 1996; Hunt et al., 1996; Watson et al., 1996) and reduce the duration of the activated GTP-bound state of the $\alpha$ subunits. To date, eighteen RGS proteins have been identified in mammalian tissues; all are highly homologous within an 130 amino acid RGS domain (Koelle and Horvitz, 1996; Siderovski et al., 1996). In vitro assays indicate that several RGS proteins stimulate the GTPase activity of the $\mathrm{G}_{\mathrm{i}}$ subfamily (Berman and Gilman, 1998), whereas RGS4 stimulates both $\mathrm{G}_{\mathrm{i}} \alpha$ and $\mathrm{G}_{\mathrm{q}} \alpha$ (Hepler et al., 1997; Huang et al., 1997; Yan et al., 1997). RGS family members typically do not stimulate the GTPase activity of $\mathrm{G}_{\mathrm{s}} \alpha$; the only exception is a truncated form of RGS3 (Chatterjee et al., 1997).

Here, we report that mammalian RGS2 mRNA is rapidly and transiently upregulated in brain neurons by synaptic activity. RGS2 appears to act selectively to increase the GTPase activity of $\mathrm{G}_{\mathrm{q}} \alpha$ when single-turnover assays are performed in solution. However, RGS2 also activates the GTPase activity of $\mathrm{G}_{\mathrm{i}} \alpha$ when the G-protein is reconstituted in phospholipid vesicles with M2 muscarinic acetylcholine receptors (mAChRs). Together, these finding suggest a novel mechanism that may be important in long-term neuronal responses to synaptic activity.

\section{MATERIALS AND METHODS}

Animals and supplies. Adult male rats (Sprague Dawley or Fischer-344) were used in studies of RGS regulation. Developmental studies used male and female Sprague Dawley pups of the indicated age. Radiochemicals were obtained from New England Nuclear Life Science Products. All other reagents were from Fisher Scientific (Houston, TX) and Sigma (St. Louis, MO), unless specifically noted.

Northern analysis. This procedure was performed as described previously (Linzer and Nathans, 1983) with $2 \mu \mathrm{g}$ of poly $\left(\mathrm{A}^{+}\right) \mathrm{RNA}$ per lane. The cDNA probe used for Northern analysis of RGS2 was a $1 \mathrm{~kb}$ fragment cloned by differential screening of an oligo-dT primed brain library, as described previously (Lyford et al., 1995), and included a 3' UTR sequence. The cDNA fragment was labeled by the random priming technique (Pharmacia, Piscataway, NJ) using $\left[\alpha^{-32} \mathrm{P}\right] \mathrm{dCTP}$.

Reverse Northern analysis. Plasmids containing the indicated cDNAs were linearized with the appropriate restriction enzymes, and $1 \mu \mathrm{g}$ of each plasmid was loaded per lane and electrophoresed in $1.5 \%$ agarose gels. Three identical gels were prepared; after denaturation and neutralization, the cDNAs were transferred to nitrocellulose. Adult rats were pretreated with cycloheximide $(\mathrm{CH})$ and received a maximal electroconvulsive seizure (MECS) as described below (Materials and Methods, Electrophysiology). Control rats were either naive or treated with $\mathrm{CH}$ only. Poly $\left(\mathrm{A}^{+}\right)$RNA was isolated separately from three individual samples using Micro Fastrack (Invitrogen, San Diego, CA), and nonradioactive double-stranded cDNA was synthesized using an oligo-dT primer with Superscript reverse transcriptase (Life Technologies, Gaithersburg, MD) as described previously (Lanahan et al., 1997). The reaction was terminated and extracted with phenol, and cDNA was precipitated with ethanol in the presence of glycogen. The precipitated cDNA mix was then chromatographed over a NICK column (Pharmacia) and reprecipitated to remove free nucleotides that might hamper the radiolabeling of the cDNA. cDNA was radiolabeled by random priming
(Pharmacia) with $\left[\alpha^{-32} \mathrm{P}\right] \mathrm{dCTP}$ to a specific activity of $4 \times 10^{9} \mathrm{cpm} / \mu \mathrm{g}$. Identical blots were prehybridized overnight at $68^{\circ} \mathrm{C}$ in $5 \times \mathrm{SSC}, 5 \times$ Denhardt's solution, $10 \mathrm{~mm}$ EDTA, $0.2 \%$ SDS, $50 \mathrm{~mm} \mathrm{NaPO}_{4}$, pH 7.0, and $100 \mu \mathrm{g} / \mathrm{ml}$ boiled salmon sperm DNA. Three blots were then hybridized overnight in freshly prepared hybridization solution containing $5 \times 10^{6} \mathrm{cpm} / \mathrm{ml}$ appropriate ${ }^{32} \mathrm{P}$-labeled cDNA probe. Filters were washed at room temperature in $2 \times$ SSC and $0.2 \%$ SDS and then washed in $1 \times \mathrm{SSC}$ and $0.2 \%$ SDS at $68^{\circ} \mathrm{C}$. Levels of hybridization were quantitated using a PhosphorImager (Molecular Dynamics, Sunnyvale, CA). Blotted cDNA included the following: c-jun and zif268 (Saffen et al., 1988); c-fos (Morgan et al., 1987); $\beta$-tubulin, glucose 6 phosphate dehydrogenase (G6PD), RGS2, RGS3, RGS7, and RGS10 (Koelle and Horvitz, 1996); RGS4 (Berman et al., 1996); and RGS12 and RGS14 (Snow et al., 1997). The size of the RGS fragments were 1.6 (RGS2), 0.24 (RGS3), 0.7 (RGS4), 1.2 (RGS7), 0.24 (RGS8 and RGS10), 0.6 (RGS12), and 0.9 (RGS14) kb. Because tissue cDNA is labeled by random priming, it is anticipated that the sensitivity of reverse Northern analysis may be influenced by the size of the cDNA insert on the blot. For a given tissue mRNA, only those labeled cDNAs that include sequence that is represented in the cloned fragment will hybridize. Thus, the sensitivity of this assay is likely to be greatest for those family members with the largest inserts.

In situ hybridization. Freshly dissected brain tissue was rapidly frozen in plastic molds placed on a dry ice-ethanol slurry as described previously (Cole et al., 1990).

Electrophysiology. MECS stimulation for blot analysis was performed as follows. Adult rats were pretreated with $\mathrm{CH}(20 \mathrm{mg} / \mathrm{kg}$, i.p.) and received an MECS using a constant current signal generator (ECT unit, Ugo Basil) as described previously (Cole et al., 1990). As a negative control, rats were untreated or treated with $\mathrm{CH}$ only. For in situ studies, rats were treated with MECS but not $\mathrm{CH}$. For long-term potentiation (LTP) studies, Fischer-344 rats were implanted bilaterally with stimulating and recording electrodes in the perforant path and hilus of the dentate gyrus as described previously (Worley et al., 1993). Rats were allowed to recover for at least 2 weeks before any recordings were performed. Fourteen chronically implanted rats received high frequency (HF) stimulation in one hemisphere and low frequency stimulation in the other hemisphere. Electrical stimuli consisted of $200 \mathrm{msec}$ diphasic constant current pulses given at a stimulus intensity of $500 \mathrm{~mA}$. The low frequency test stimulation was delivered at $0.1 \mathrm{~Hz}$, and the HF stimulation parameters consisted of 50 repetitions of a $20 \mathrm{msec}$ train (i.e., eight pulses) delivered at $400 \mathrm{~Hz}$ (400 total pulses). The HF parameters reliably induce LTP (Dragunow et al., 1989; Jeffery et al., 1990; Worley et al., 1993). After this treatment, the rats were killed at either $0.5(n=$ $2), 1(n=2)$, or $2 \mathrm{hr}(n=2)$. Some rats received an intraperitoneal injection with the NMDA-type glutamate receptor antagonist MK-801 $(1 \mathrm{mg} / \mathrm{kg}) 30 \mathrm{~min}$ before the HF stimulus.

Recombinant RGS2 expression. Recombinant RGS2 was expressed as described previously (Lalumiere and Richardson, 1995). An expressed sequence tag (EST) containing the full open-reading frame of mouse RGS2 was identified within the Amgen (Thousand Oaks, CA) EST Program database and cloned within the NheI site of the baculoviral expression vector pETL, downstream of the polyhedron promoter (Lalumiere and Richardson, 1995). Recombinant baculovirus was generated using BaculoGold baculoviral DNA (PharMingen, San Diego, CA). Spodoptera frugiperda (Sf9) cells were cultured at $27^{\circ} \mathrm{C}$ in spinner vessels to a density of $1 \times 10^{6}$ cells/ml Grace's media (Life Technologies), supplemented with $10 \%$ fetal calf serum. Sf9 cells were infected at a multiplicity of infection of 5.0 with recombinant baculovirus, harvested by centrifugation at $72 \mathrm{hr}$ after infection, swollen in 10 volumes of hypotonic lysis buffer (in mu: 20 Tris- $\mathrm{HCl}, \mathrm{pH} 8.0,10 \mathrm{KCl}, 2$ EDTA, 0.5 EGTA, 5 DTT, and protease inhibitors), and lysed with a dounce homogenizer. The lysate was clarified by low- and high-speed centrifugations $(12,000 \times g$ for $20 \mathrm{~min}$ and $100,000 \times g$ for $1 \mathrm{hr})$, and the supernatant was passed through a Q Sepharose FF anion exchange column (Pharmacia) equilibrated with lysis buffer. The column void fraction was dialyzed against SP Sepharose FF equilibration buffer [in mM: 50 4-mopholinepropanesulfonic acid (MOPS) (Boehringer Mannheim, Indianapolis, IN), $\mathrm{pH}$ 7.4, $10 \mathrm{KCl}, 2$ EDTA, $5 \mathrm{DTT}, 10 \mathrm{KCl}$, and protease inhibitors] (Pharmacia) and passed through a SP Sepharose FF cation exchange column (Pharmacia) equilibrated in the same buffer. The bound recombinant RGS2 was eluted with a $0-500 \mathrm{~mm} \mathrm{NaCl}$ salt gradient. The fractions containing RGS2 were pooled, dialyzed against storage buffer (in mM: 10 MOPS, pH7.4, 1 EDTA, and 2 DTT), and stored at $-80^{\circ} \mathrm{C}$. 
Preparation of recombinant G-proteins and RGS4. Recombinant R183C $\mathrm{G}_{\mathrm{q}} \alpha$ and $\mathrm{G}$-protein $\beta \gamma$ subunits were purified after expression in Sf9 cells (Biddlecome et al., 1996), as were M2 mAChRs (Parker et al., 1991). $\mathrm{G}_{\mathrm{s}} \alpha$ and myristoylated $\mathrm{G}_{\mathrm{o}} \alpha$ and $\mathrm{G}_{\mathrm{i}} \alpha 1$ were synthesized and purified from Escherichia coli (Linder et al., 1991; Lee et al., 1994). Recombinant RGS4 was purified from E. coli as described previously (Berman et al., 1996) and was generously provided by David Berman (Department of Pharmacology, University of Texas Southwestern Medical Center, Dallas, TX).

Preparation of $\left[\gamma_{-}{ }^{32} P\right] G T P-G \alpha$ substrates for GAP assays. Purified $\mathrm{R} 183 \mathrm{C} \mathrm{G} \mathrm{G}_{\mathrm{q}} \alpha(\sim 1 \mathrm{nM}$ final concentration $)$ was incubated with $\left[\gamma_{-}{ }^{32} \mathrm{P}\right] \mathrm{GTP}$ (specific activity, $\sim 500 \mathrm{cpm} / \mathrm{pmol}$ ) for $2-3 \mathrm{hr}$ at $20^{\circ} \mathrm{C}$ in a solution containing: $10 \mu \mathrm{M}$ GTP, $5.5 \mathrm{mM}$ 3-[(3-cholamidopropyl) dimethylammonio]-1-propane-sulfonate (CHAPS) (Sigma), $50 \mathrm{~mm} \mathrm{Na}$ HEPES, pH 7.5, 1 mм DTT, 1 mм EDTA, $0.9 \mathrm{~mm} \mathrm{MgSO}_{4}, 0.1 \mathrm{mg} / \mathrm{ml} \mathrm{BSA,} 30 \mathrm{~mm}$ $\left(\mathrm{NH}_{2}\right)_{2} \mathrm{SO}_{4}$, and $4 \%$ glycerol. Other $\mathrm{G} \alpha$ proteins were incubated with $\left[\gamma_{-}{ }^{32} \mathrm{P}\right] \mathrm{GTP}$ in the absence of $\mathrm{MgSO}_{4}$ as described previously (Berman et al., 1996). The mixture containing GTP-bound $\mathrm{G} \alpha$ proteins was gel filtered on G-25 Sephadex, equilibrated with $1 \mathrm{mM} \mathrm{CHAPS}$ buffer (1 mM CHAPS, 50 mm Na HEPES, pH 7.5, 1 mm EDTA, 0.9 mm $\mathrm{MgSO}_{4}, 1 \mathrm{~mm}$ DTT, and $0.018 \mathrm{mg} / \mathrm{ml} \mathrm{BSA})$. The flow-through was diluted fourfold into octylglucoside $(\mathrm{OG})$ buffer $(0.1 \%$ octyl glucopyranoside, $20 \mathrm{~mm} \mathrm{Na}$ HEPES, pH 7.5, 80 mм NaCl, 1 mм DTT, 1 mm EDTA, 0.9 mм $\mathrm{MgSO}_{4}$, $0.01 \mathrm{mg} / \mathrm{ml} \mathrm{BSA}$, and $1 \mathrm{~mm}$ GTP) and kept on ice until needed. All of the manipulations above were conducted in the absence of $\mathrm{MgSO}_{4}$ for $\mathrm{G} \alpha$ proteins other than $\mathrm{G}_{\mathrm{q}} \alpha$.

In vitro GAP activity. GAP activity was measured by adding $\mathrm{G} \alpha-\mathrm{GTP}$ substrate to RGS sample and OG buffer (supplemented with $9 \mathrm{~mm}$ $\mathrm{MgSO}_{4}$ when $\mathrm{G}_{\mathrm{s}} \alpha$, myr-G $\mathrm{G}_{\mathrm{o}} \alpha$, or myr- $\mathrm{G}_{\mathrm{i}} \alpha$ were used). One hundred microliter aliquots were withdrawn at the indicated times and were quenched in $900 \mu \mathrm{l}$ of $5 \%$ (wt/vol) Norit A charcoal in $50 \mathrm{~mm} \mathrm{NaH} \mathrm{PO}_{4}$. The charcoal was pelleted, and $600 \mu$ l of supernatant containing ${ }^{32} \mathrm{Pi}$ was counted. GTPase assays conducted in a buffer containing $0.5 \%$ Lubrol (Berman et al., 1996) yielded results similar to those obtained in $0.1 \%$ OG.

$M 2 \mathrm{mAChR}(\mathrm{Gi})$ reconstitution assay. The steady-state GTPase activity of $\mathrm{G}_{\mathrm{i}} \alpha 1$ was measured in reconstituted vesicles containing M2 mAChRs and heterotrimeric $\mathrm{G}_{\mathrm{i}} 1$ (Parker et al., 1991; Wong and Ross, 1994) (a generous gift from Dr. Yaping Tu, University of Texas Southwestern Medical Center). The vesicles were equilibrated for $5 \mathrm{~min}$ at $20^{\circ} \mathrm{C}$ with carbachol $(1 \mathrm{mM})$ or atropine $(20 \mu \mathrm{M})$ in the presence of RGS2 or RGS4 (500 nM final concentration) in buffer containing: $4 \mu \mathrm{M}$ GTP, $20 \mathrm{~mm} \mathrm{Na}$ HEPES, pH 8.0, $50 \mathrm{~mm} \mathrm{NaCl}, 2 \mathrm{~mm} \mathrm{MgCl}_{2}$, and $1 \mathrm{~mm}$ EDTA. The assay was initiated by the addition of an equal volume $(30 \mu \mathrm{l})$ of the same buffer without unlabeled GTP but containing $10^{6} \mathrm{cpm}$ of $\left[\gamma^{-32} \mathrm{P}\right] \mathrm{GTP}$. Reactions were terminated after $15 \mathrm{~min}$ at $20^{\circ} \mathrm{C}$ by the addition of $900 \mu \mathrm{l}$ of $5 \%$ Norit A charcoal in $50 \mathrm{~mm} \mathrm{NaH}{ }_{2} \mathrm{PO}_{4}$. The samples were centrifuged, and the supernatant was counted to determine the content of ${ }^{32} \mathrm{Pi}$.

Cell culture. SV-40 transformed African Green Monkey Kidney (COS) cells (American Type Culture Collection, Manassas, VA) were cultured in DMEM supplemented with fetal bovine serum (10\%). Approximately $2 \times 10^{6}$ cells in a plate were transfected by the calcium phosphate method with various combinations of pRK5-mAChR $(6 \mu \mathrm{g})$, pMT2-HAERK1 $(6 \mu \mathrm{g})$, and pRK5-RGS $(10 \mu \mathrm{g})$. The total amount of plasmid DNA was adjusted to $22 \mu \mathrm{g} /$ plate with vector DNA when necessary. After $40 \mathrm{hr}$, cells were left untreated or were stimulated with the agonist and lysed at $4^{\circ} \mathrm{C}$ in a buffer containing: $20 \mathrm{mM}$ HEPES, pH 7.5, $10 \mathrm{~mm}$ EGTA, $40 \mathrm{~mm} \beta$-glycerophosphate, $1 \% \mathrm{NP}-40,2.5 \mathrm{~mm} \mathrm{MgCl}_{2}, 1 \mathrm{~mm}$ dithiothreitol, $2 \mathrm{~mm}$ sodium vanadate, $1 \mathrm{~mm}$ phenylmethylsulfonylfluoride, $20 \mu \mathrm{g} / \mathrm{ml}$ aprotinin, and $20 \mu \mathrm{g} / \mathrm{ml}$ leupeptin. The lysate was centrifuged at $14,000 \times g$ for $20 \mathrm{~min}$ at $4^{\circ} \mathrm{C}$, and proteins were immunoprecipitated and assayed for kinase activity.

Immunoprecipitation and MAP kinase assay. For the MAP kinase assay, proteins from clarified supernatants were immunoprecipitated with monoclonal antibody to hemagglutinin (HA) 12CA5 (Boehringer Mannheim) for $2 \mathrm{hr}$ at $4^{\circ} \mathrm{C}$, and immunocomplexes were recovered with Immobilized Protein G (Pierce, Rockford, IL). Bound proteins were washed three times with lysis buffer supplemented with $2 \mathrm{~mm}$ sodium vanadate, once with $0.5 \mathrm{M} \mathrm{LiCl}$ in $100 \mathrm{~mm}$ Tris, $\mathrm{pH} 7.5$, and once with kinase reaction buffer (in mM: 10 MOPS, pH 7.5, 12.5 $\beta$-glycerophosphate, $7.5 \mathrm{MgCl}_{2}, 0.5$ EGTA, 0.5 sodium fluoride, and 0.5 sodium vanadate). Reactions were done in $60 \mu$ l volumes of kinase reaction buffer $\left[10 \mu \mathrm{Ci} /\right.$ reaction $\left[\gamma^{-32} \mathrm{P}\right] \mathrm{ATP}, 50 \mu \mathrm{M}$ unlabeled ATP, and $0.25 \mathrm{mg} / \mathrm{ml}$ myelin basic protein (MBP) (Sigma)] at $30^{\circ} \mathrm{C}$ for $30 \mathrm{~min}$. Reactions were terminated by the addition of a $2 \times$ SDS buffer. Samples were boiled, and proteins were separated by SDS-PAGE (12\% gel).
Phosphorylated MBP was visualized by autoradiography and was quantified by liquid scintillation counting. Parallel samples were immunoprecipitated with antibody to HA and processed for protein immunoblot analysis with a ERK1-specific antibody (Santa Cruz Biotechnology, Santa Cruz, CA).

\section{RESULTS}

\section{Selective and robust induction of RGS2 mRNA in response to neuronal activation}

In previous studies, we developed differential and subtractive cloning strategies to identify mRNAs that are rapidly upregulated in the hippocampus by excitatory activity (Yamagata et al., 1994; Brakeman et al., 1997; Lanahan et al., 1997). In the present study, a phage cDNA library was prepared from rat hippocampus $4 \mathrm{hr}$ after systemic administration of $\mathrm{CH}$. $\mathrm{CH}$ blocks protein synthesis and stabilizes many mRNAs that normally turn over rapidly. Rats additionally received MECS at $30 \mathrm{~min}$ intervals for six treatments before being killed. MECS is a simple and reliable means to induce the expression of immediate early genes (IEGs) in the hippocampus and causes long-term enhancement of synaptic contacts in the hippocampus (Barnes et al., 1994; Lanahan et al., 1997). The cDNA library was then subtracted twice using RNA prepared from naive rat hippocampus and once with RNA from liver. The subtracted library was then differentially screened using radiolabeled cDNA prepared from naive control and MECS-CH rat hippocampus. Nucleotide sequence analysis of one of the differentially expressed cDNAs identified it as RGS2.

To explore the dynamic regulation of RGS mRNA expression, we first performed Northern blot analysis of poly $\left(\mathrm{A}^{+}\right)$RNA from hippocampus of naive and MECS-CH-stimulated rat hippocampus (Fig. $1 A$ ). The RGS2 cDNA probe detected a $1.8 \mathrm{~kb}$ message that was strongly induced by MECS-CH. The size of the mRNA was identical to that reported for the RGS2 transcript (Wu et al., 1995). The rapid induction of RGS2 mRNA in the presence of $\mathrm{CH}$ suggests that it is regulated as an IEG in brain.

To determine whether other members of the RGS family are regulated by MECS-CH in the hippocampus, we used the reverse Northern strategy (Fig. 1B). With this technique (Lanahan et al., 1997), levels of tissue mRNA are assessed by monitoring the intensity of the hybridization of radiolabeled cDNA prepared from tissue RNA to Southern blots containing cloned cDNAs of multiple candidate IEGs. We prepared poly $\left(\mathrm{A}^{+}\right) \mathrm{RNA}$ individually from the hippocampus of a control rat and from an MEC$\mathrm{S}-\mathrm{CH}$ rat and converted them to double-strand cDNAs. cDNA was labeled by random priming and used as a hybridization probe. Southern blots were prepared using a panel of eight RGS cDNAs, as well as representative known IEGs and constitutively expressed genes (Fig. $1 B$ ). Duplicate blots were probed with cDNA from the hippocampus of naive control (Fig. $1 B, t o p$ ) and MECS-CH (Fig. $1 B$, bottom) rats. In Figure $1 B$, comparison of the top and bottom blots confirms that MECS stimulation increases mRNA levels of representative IEGs (c-jun, c-fos, and zif268), whereas $\beta$-tubulin and G6PD were essentially unchanged. Consistent with the Northern blot analysis, RGS2 mRNA was strongly increased by MECS-CH. In contrast, hybridization to RGS3, RGS4, RGS7, RGS8, RGS10, RGS12, and RGS14 was not increased by MECS-CH. To permit quantitative comparisons between blots, the hybridization signal was determined using a PhosphorImager (Molecular Dynamics) and normalized to G6PD (Fig. 1C). Of the eight RGS subtypes surveyed, only RGS2 showed a significant induction with MECS-CH. In this analysis, RGS2 mRNA was induced more than sevenfold. Reverse Northern analysis provides a comparison of the relative levels of ex- 


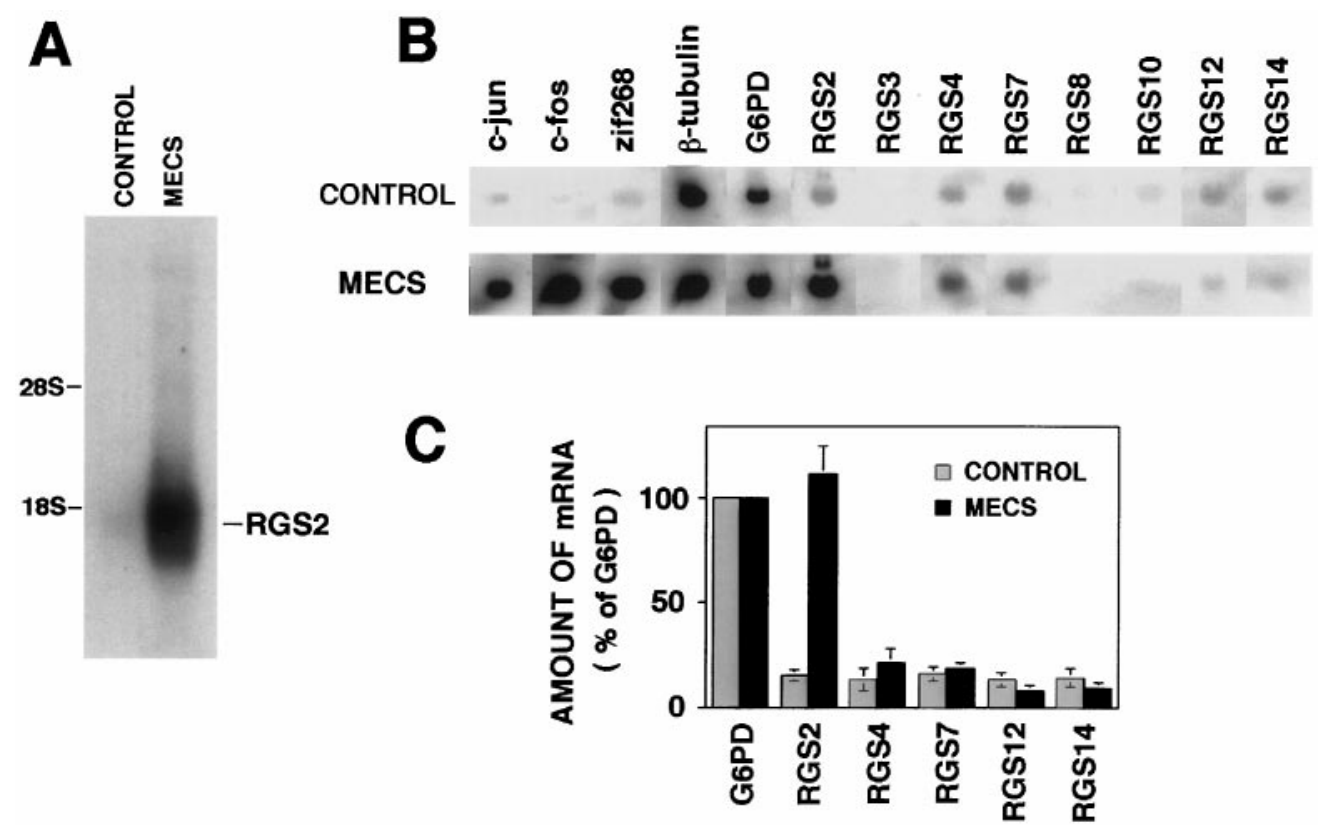

Figure 1. Selective induction of RGS2 mRNA in hippocampus by seizure. $A$, Northern blot analysis of $2 \mu \mathrm{g} /$ lane poly(A ${ }^{+}$) RNA prepared from hippocampus under basal conditions and after $4 \mathrm{hr}$ MECS- $\mathrm{CH}$ induction. The blot was probed with a $1 \mathrm{~kb}$ cDNA corresponding to the $3^{\prime}$ nt sequence of RGS2. Note robust induction of an $\sim 1.8 \mathrm{~kb}$ transcript. $B$, Analysis of RGS family mRNA levels after seizure by reverse Northern analysis. Southern blots were prepared using $1 \mu \mathrm{g}$ of each RGS cDNA, as well as positive and negative control genes. Duplicated Southern blots were probed with radiolabeled cDNA prepared from hippocampus of naive control (top) and MECS-stimulated (bottom) rats. Comparison of top and bottom blots demonstrates that MECS-CH increases the intensity of hybridization to RGS2, as well as representative IEGs (c-jun, $c$-fos, and zif268). $\beta$-tubulin and G6PD are constitutively expressed and provide a comparison for genes that are induced by MECS. $C$, Quantitation of RGS family mRNA. Levels of hybridization signal from reverse Northern blots were quantitated using a PhosphorImager (Molecular Dynamics) and are presented as percentage of G6PD level on each blot. Data are mean \pm SEM of triplicate determinations from a representative experiment. Of the eight RGS subtypes surveyed, only RGS2 showed robust induction (7.3-fold). Increases for other RGS genes were calculated to be 1.7- (RGS4), 1.2- (RGS7), 0.58- (RGS12), and 0.65 -fold (RGS14). Similar results were obtained in two independent experiments.

pression; however, because of limitations in sensitivity of the reverse Northern technique (see Materials and Methods), we cannot exclude the possibility that these RGS genes might also be regulated by activity at lower levels. These results indicate that several RGS family members are expressed in the hippocampus and that RGS2 mRNA is selectively induced by MECS-CH. Although RGS2 mRNA is induced by $\mathrm{CH}$ alone in blood mononuclear cells (Siderovski et al., 1994), our reverse Northern analyses indicate that RGS2 is not induced by $\mathrm{CH}$ alone in the rat brain (data not shown).

\section{Expression and activity-dependent induction of RGS2 mRNA in cerebral cortex and hippocampus}

To examine the cellular distribution of natural (control) and induced expression of RGS2, we performed in situ hybridization (Fig. 2). Expression was examined in the forebrain of a naive rat and compared with expression in rats that received a single MECS and were killed 0.5, 1, or $2 \mathrm{hr}$ afterward (Fig. 2A). RGS2 mRNA is naturally expressed in cortex and hippocampus, with prominent cellular localization to granule and pyramidal neurons of the hippocampus and layer 2 neurons of the pyriform cortex. Within 30 min after MECS, RGS2 mRNA is seen to be induced in neuronal cell populations of the hippocampus and throughout the cortex, amygdala regions, and striatum. These results indicate that a single seizure is sufficient to induce RGS2. Additionally, because rats did not receive $\mathrm{CH}$ in these experiments, we conclude that RGS2 induction does not depend on concomitant $\mathrm{CH}$ treatment. No induction is observed in the thalamus. Expression in cortex and hippocampus remains elevated at both the 1 and 2 hr time points after MECS. To obtain a more complete time course of induction, we repeated in situ analysis with individual hippocampi harvested from rats as long as $8 \mathrm{hr}$ after MECS (Fig. $2 B$ ). In the pyramidal cell layer of hippocampus and the granule cell layer of dentate gyrus, RGS2 mRNA levels remain elevated for $2 \mathrm{hr}$ after stimulation and return to basal levels by $8 \mathrm{hr}$. Thus, the RGS2 mRNA increase occurs rapidly and transiently in discrete brain regions.

\section{RGS2 mRNA is induced in brain neurons by synaptic activity in association with synaptic enhancement}

The rapid induction of RGS2 mRNA after MECS suggests that RGS2 may be regulated by excitatory synaptic mechanisms. To test this hypothesis, granule cells of the adult hippocampus were synaptically stimulated by activating their major afferent projections from the entorhinal cortex using a chronic in vivo electrophysiological preparation in unanesthetized awake behaving rats (McNaughton et al., 1986). The intensity and frequency of the synaptic stimulus can be precisely controlled in this preparation, and it is used extensively to study mechanisms of LTP. Stimulation administered at $0.1 \mathrm{~Hz}$ at an intensity level sufficient to activate granule cell action potentials did not result in increased RGS2 mRNA expression in these cells (Fig. 2C, top left). In contrast, stimuli of the same intensity, when administered at a HF $(400 \mathrm{~Hz})$, resulted in a rapid and robust induction of RGS2 mRNA in the granule cells (Fig. $2 C$, top right). RGS2 mRNA was induced in each of four animals killed $0.5-1 \mathrm{hr}$ after the $\mathrm{HF}$ stimulus $(n=4)$. Thus, the rapid time course of RGS2 mRNA induction after the HF stimulus is similar to that produced by 


\section{A POST-SEIZURE} TIME COURSE
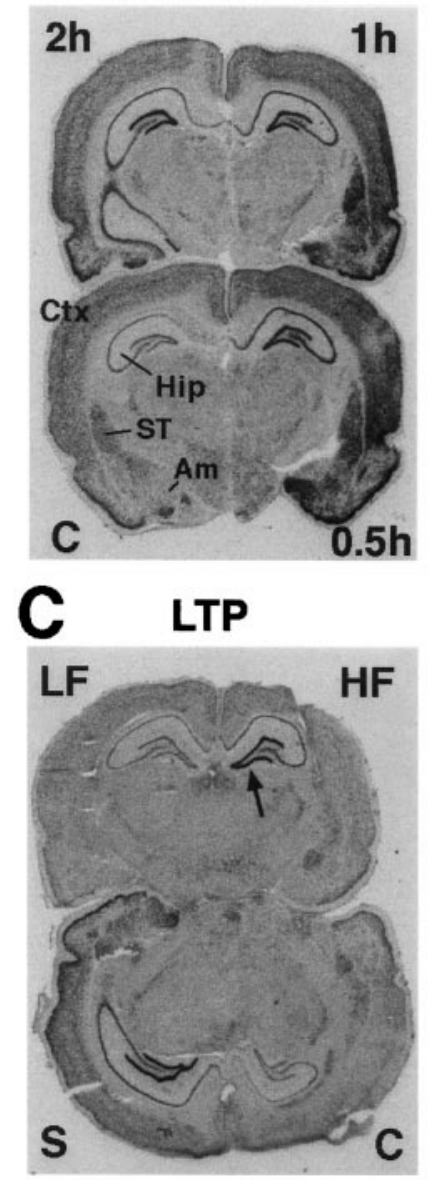

\section{B POST-SEIZURE TIME COURSE}
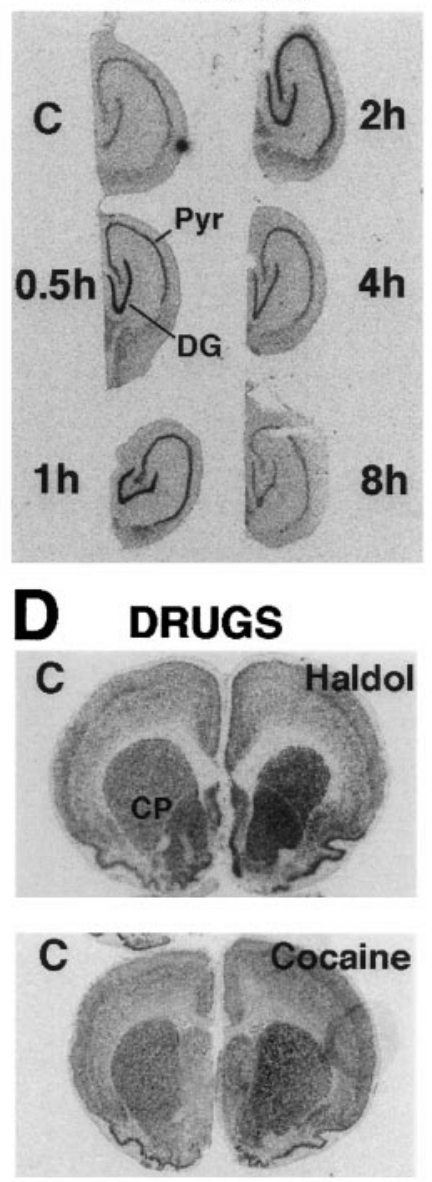

Figure 2. In situ analysis of RGS2 expression in brain. A, Postseizure time course of RGS2 mRNA induction in the whole brain. Adult rats received a single MECS and were killed $0.5,1$, or $2 \mathrm{hr}$ later. RGS2 mRNA rapidly increases within $0.5 \mathrm{hr}$ after stimulation, and peak mRNA levels are detected $0.5-1 \mathrm{hr}$ after stimulation. The increase of RGS2 mRNA is seen in regions including the cerebral cortex, hippocampus, caudate putamen, and amygdala nucleus. The same hybridization patterns were repeated in independent experiments $(n=2-3)$. Postseizure time course failed to detect a change in the levels of RGS4 and RGS7 mRNA expression (data not shown). Ctx, Cortex; Hip, hippocampus; Am, amygdala; $S T$, striatum. $B$, Postseizure time course of RGS2 mRNA in the hippocampus. Adult rats received a single MECS and were killed 0.5, 1, 2 , 4, or $8 \mathrm{hr}$ later. RGS2 mRNA rapidly increases in the pyramidal layer of hippocampus and the dentate gyrus within $0.5 \mathrm{hr}$ after stimulation, and peak mRNA levels are detected $0.5-2 \mathrm{hr}$ after stimulation and return to basal levels by $8 \mathrm{hr}$. The same hybridization patterns were repeated in independent experiments $(n=2-3)$. Pyr, Pyramidal cell layer; $D G$, dentate gyrus. $C$, Induction of RGS2 mRNA in LTP paradigm. Chronically implanted awake and behaving animals received a high frequency $(H F)$ synaptic stimulus to the left dentate gyrus and an identical number of stimuli at low frequency $(L F)$ to the right. Rats were killed $1 \mathrm{hr}$ after the HF stimulus. RGS2 mRNA is strongly induced in the hippocampal granule cells by the HF stimulus. The bottom brain image is a composite that includes a half brain from naive control ( $C$ side) and MECSstimulated $(S$ side) rats. Identical results were observed in four independent experiments. The LTP studies failed to detect a change in the levels of RGS4 and RGS7 mRNA using adjacent sections (data not shown). $D$, Induction of RGS2 mRNA by administration of haloperidol (haldol) and cocaine. Adult rats were injected with haloperidol $(1 \mathrm{mg} / \mathrm{kg}$, i.p. $)$ or cocaine $(20 \mathrm{mg} / \mathrm{kg}$, i.p.) and were killed 0.5 , 1, or $2 \mathrm{hr}$ later. Peak induction occurred $30 \mathrm{~min}$ after drug administrations. RGS2 mRNA is induced in the striatum by haldol (approximately twofold), but a minimal change was seen after this dose of cocaine. The same results were repeated in two independent experiments $(n=2)$. $C P$, Caudate putamen. seizure-induced neuronal activation in the hippocampus. RGS2 mRNA induction was blocked by pretreatment of rats with the NMDA-type glutamate receptor antagonist MK-801 (1 mg/kg; $n=2)$, indicating that induction in this paradigm is dependent on synaptic activation of the NMDA receptor. The magnitude of the RGS2 mRNA induction by the HF stimulus was also comparable to that after the seizure-induced activation (Fig. 2C); however, unlike MECS, which induced RGS2 mRNA in the cerebral cortex and hippocampus (Fig. 2C, lower left), the HF stimulus induced RGS2 only in the hippocampus. The HF stimulation parameters determined to induce RGS2 are identical to those determined previously to induce LTP, and in each of our preparations, the $\mathrm{HF}$ stimulus induced robust synaptic enhancement. However, no change was detected in the level of RGS4 and RGS7 mRNA by HF stimulus in adjacent tissue sections (data not shown). These observations indicate that RGS2 is rapidly and transiently regulated by physiological synaptic activity.

\section{The effects of haloperidol and cocaine on RGS2 mRNA level in striatum}

To evaluate whether RGS genes might be regulated by dopaminedependent mechanisms, we examined the levels of three RGS mRNAs in the rat striatum after the administration of haloperidol or cocaine. Rats were injected with haloperidol or cocaine and were killed $0.5,1$, or $2 \mathrm{hr}$ later. Haloperidol is a dopamine receptor antagonist and is widely used as an antipsychotic drug (Carlson et al., 1986; Kandel, 1991). RGS2 mRNA expression was rapidly induced in the caudate putamen within 30 min after the haloperidol administration, suggesting regulation by dopamine receptor mechanisms (Fig. 2D). In contrast, cocaine (20-30 $\mathrm{mg} / \mathrm{kg}$, i.p.), an inhibitor of catecholamine reuptake by neurons that induces several other IEGs in the brain (Bhat and Baraban, 1993; Brakeman et al., 1997), caused a minimal level of change in RGS2 mRNA (Fig. 2D). In the analysis of time courses, the largest level of induction was seen $30 \mathrm{~min}$ after the administration of these drugs. No change was detected in the level of RGS4 and RGS7 mRNA after administration of these drugs (data not shown).

\section{Extensive codistribution of RGS2, RGS4, and RGS7 in cortex and hippocampus}

We compared the localization of mRNAs for RGS2, RGS4, and RGS7 by in situ hybridization (Fig. 3). Comparisons were performed using paired half brains from naive control and MECSstimulated (30 $\mathrm{min})$ rats. This analysis demonstrated an extensive anatomic distribution of RGS2 induction by MECS in cortex, amygdala, hippocampus, and caudate putamen. Expression of RGS4 and RGS7 in these brain regions was unaffected by MECS. In the naive control brain (Fig. 3, C side), RGS2, RGS4, and RGS7 showed unique and discrete localizations throughout the brain, with highest levels of expression in the cerebral and cerebellar cortex. RGS4 mRNA was enriched in the pyriform cortex, caudate putamen, amygdala nucleus, Purkinje cell layers of cerebellum, and the pyramidal cell layer of the hippocampus. In addition, RGS4 mRNA was enriched in the principal nuclei of the thalamus, and this contrasts with RGS2, which was not enriched in thalamus. The distribution of RGS7 mRNA is similar to RGS4 and is the most widespread of the three surveyed RGS mRNAs. Overall levels of RGS7 hybridization were less than either RGS2 or RGS4. RGS7 is expressed in cerebral neocortex, pyriform cortex, principal nucleus of thalamus, hippocampus, cerebellar granule cell layer, and both the pyramidal cell layer and dentate 
RGS2
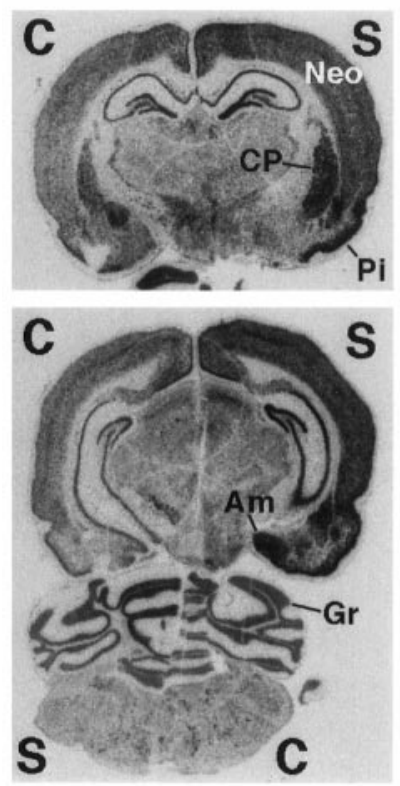

RGS4
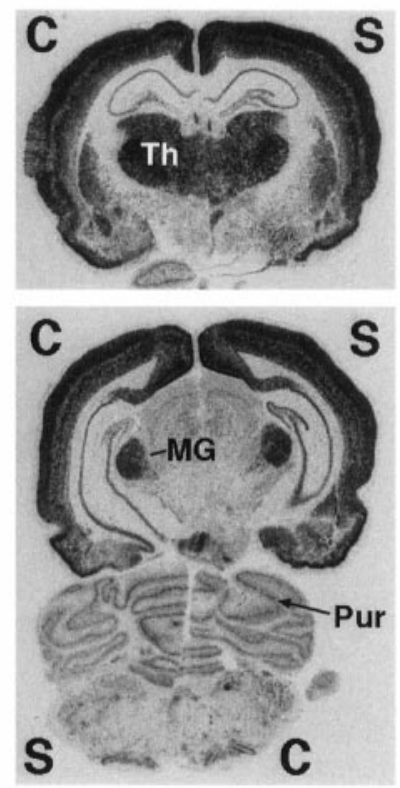

RGS7
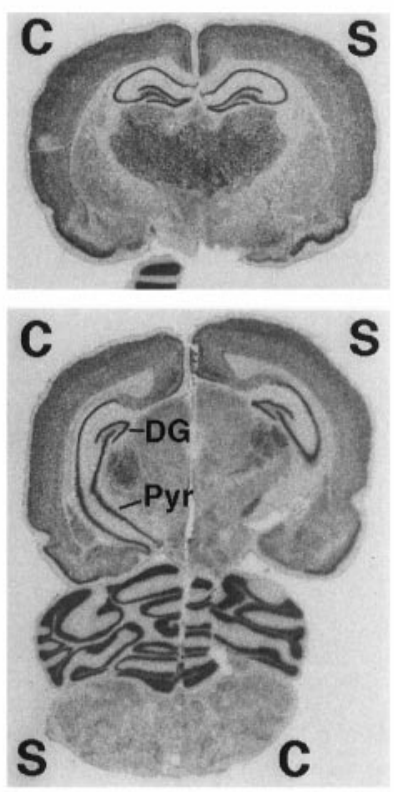

Figure 3. Comparative localizations of RGS2, RGS4, and RGS7 mRNA in brain. The brains are composites of half brains from a naive control rat ( $C$ side) and a rat that received a single MECS stimulation $1 \mathrm{hr}$ before being killed ( $S$ side). Note that the laterality of the cerebellum is opposite of the cerebrums in the bottom panels. In the control brains, RGS2, RGS4, and RGS7 individually show discrete neuronal localization throughout the brain with high concentrations in the cortex. See Results for a more detailed discussion of the comparative distributions. Seizure produced a modest induction of RGS4 that is restricted to granule cells of the posterior hippocampus, whereas RGS7 is unchanged. RGS2 mRNA is induced by seizure in the cerebral cortex and hippocampus. For each RGS subtype, the hybridization patterns were virtually indistinguishable between rats $(n=2-5)$ and independent hybridizations $(n \geq 2)$. Neo, Neocortex; $P i$, pyriform cortex; $C P$, caudate putamen; $A m$, amygdala; $G r$, granule cell layer; $T h$, thalamus; $M G$, medial geniculate nucleus; Pur, Purkinje cell layer; $D G$, dentate gyrus; $P y r$, pyramidal cell layer. gyrus of the hippocampus. RGS7 is distinct from RGS4 in the dense staining pattern of the hippocampus and cerebellar granule cell layer. For each RGS subtype, the hybridization patterns were identical between rats $(n=2-5)$ in independent hybridizations $(n \geq 2)$. The results of a recent report of localization of RGS4 and RGS7 by in situ hybridization in the rat brain agree with our findings (Gold et al., 1997). This report clearly revealed the laminar expression pattern of RGS4 in the neocortex, with the highest concentration of nine RGS subtypes (RGS3-RGS11).

\section{RGS2 selectively accelerates GTP hydrolysis by $\mathrm{G}_{\mathrm{q}} \alpha$ in solution assays}

The dynamic changes in RGS2 expression that occur in models of neural plasticity lead us to examine the effect of RGS2 upregulation on neuronal cell function. Because RGS family members are known to accelerate the rate of GTP hydrolysis of various receptor-coupled G-proteins, we began with a biochemical characterization that examined the G-protein specificity of RGS2 using single turnover GTPase assays (Berman et al., 1996). Although such assays have been described previously for members of the $\mathrm{G}_{\mathrm{s}} \alpha, \mathrm{G}_{\mathrm{i}} \alpha$, and $\mathrm{G} 12 \alpha$ subfamilies, difficulties in preparing GTP $-\mathrm{G}_{\mathrm{q}} \alpha$ have precluded such simple measurements with this substrate. Rather, effects of RGS proteins on the GTPase activity of $G_{q} \alpha$ have required reconstitution of $G_{q}$ heterotrimer into phospholipid vesicles with an appropriate receptor (e.g., M1 mAChR) to stimulate nucleotide exchange. Berman et al. (1996) recently noted that RGS4 could accelerate the GTPase activity of the GTPase-deficient R178C mutant of $\mathrm{G}_{\mathrm{i}} \alpha$. Accordingly, the analogous mutation was made in $\mathrm{G}_{\mathrm{q}} \alpha$ (R183C), and the resultant reduction of basal GTPase activity permitted preparation of $\mathrm{R} 183 \mathrm{C} \mathrm{G}_{\mathrm{q}} \alpha$-GTP for use in single turnover assays.

Figure 4, $A-D$, demonstrates that RGS4 accelerates the rate of GTP hydrolysis by R183C $\mathrm{G}_{\mathrm{q}} \alpha, \mathrm{G}_{\mathrm{o}} \alpha$, and $\mathrm{G}_{\mathrm{i}} \alpha$ (but not $\mathrm{G}_{\mathrm{s}} \alpha$ ). These experiments substantiate previous results with RGS4 and demonstrate the utility of $\mathrm{R} 183 \mathrm{C}_{\mathrm{q}} \alpha$ for single turnover assays. In contrast, RGS2 was an effective GAP with $\mathrm{G}_{\mathrm{q}} \alpha$ but failed to have any significant effect on GTP hydrolysis by $\mathrm{G}_{\mathrm{o}} \alpha, \mathrm{G}_{\mathrm{i}} \alpha$, or $\mathrm{G}_{\mathrm{s}} \alpha$.
Further examination of RGS2 activity using a constant concentration of R183C GTP-G $\mathrm{q}_{\mathrm{q}} \alpha(0.2 \mathrm{nM})$ with increasing concentrations of RGS2 (0-500 nM) revealed that enhanced GTPase activity could be detected with RGS2 concentrations as low as $0.5 \mathrm{~nm}$ (Fig. 4E). Kinetic analysis using a two-site exponential curve fit to determine the initial rate of GTP hydrolysis revealed a 200-fold increase in the catalytic rate constant for GTP hydrolysis from $0.005 / \mathrm{min}$ to $1 / \mathrm{min}$ at maximal concentrations of RGS2. The second site from the curve-fitting analysis is consistent with the low intrinsic GTPase activity of $\mathrm{R} 183 \mathrm{C} \mathrm{G}_{\mathrm{q}} \alpha$. The results of a recent report demonstrated that RGS2 selectively inhibited $\mathrm{G}_{\mathrm{q}^{-}}$ mediated activation of phospholipase $\mathrm{C}$ in cell membranes (Heximer et al., 1997). This observation is consistent with the capacity of RGS2 to act as a GAP on $\mathrm{G}_{\mathrm{q}} \alpha$.

\section{RGS2 accelerates GTP hydrolysis by both $\mathrm{G}_{\mathrm{q}} \alpha$ and $\mathrm{G}_{\mathrm{i}} \alpha$ in reconstituted lipid vesicles}

Because all other members of the RGS protein family tested to date act as GAPs on members of the $\mathrm{G}_{\mathrm{i}}$ subfamily of G-protein $\alpha$ subunits, we explored the activity of RGS2 further in a more complex system containing $G_{i}$ heterotrimer and M2 mAChRs reconstituted into phospholipid vesicles (Parker et al., 1991). The rate of GTP hydrolysis by $\mathrm{G}_{\mathrm{i}} \alpha$ was measured in the presence of the receptor agonist carbachol and the receptor antagonist atropine (Fig. 5). As anticipated, carbachol produced a sixfold increase in the rate of GTP hydrolysis in the absence of an RGS protein. Consistent with previous results (Berman et al., 1996), addition of RGS4 caused a further 23-fold increase in the rate of GTP hydrolysis in the presence of carbachol. Surprisingly, RGS2 also stimulated GTP hydrolysis dramatically in this system, demonstrating that this RGS protein also acts as a GAP for both $\mathrm{G}_{\mathrm{i}} \alpha$ and $\mathrm{G}_{\mathrm{q}} \alpha$ if assayed under appropriate conditions.

\section{RGS2 and RGS4 inhibit MAP kinase activation by mAChR activation}

Based on biochemical studies, we examined the hypothesis that RGS2 upregulation might modulate intracellular signaling cas- 

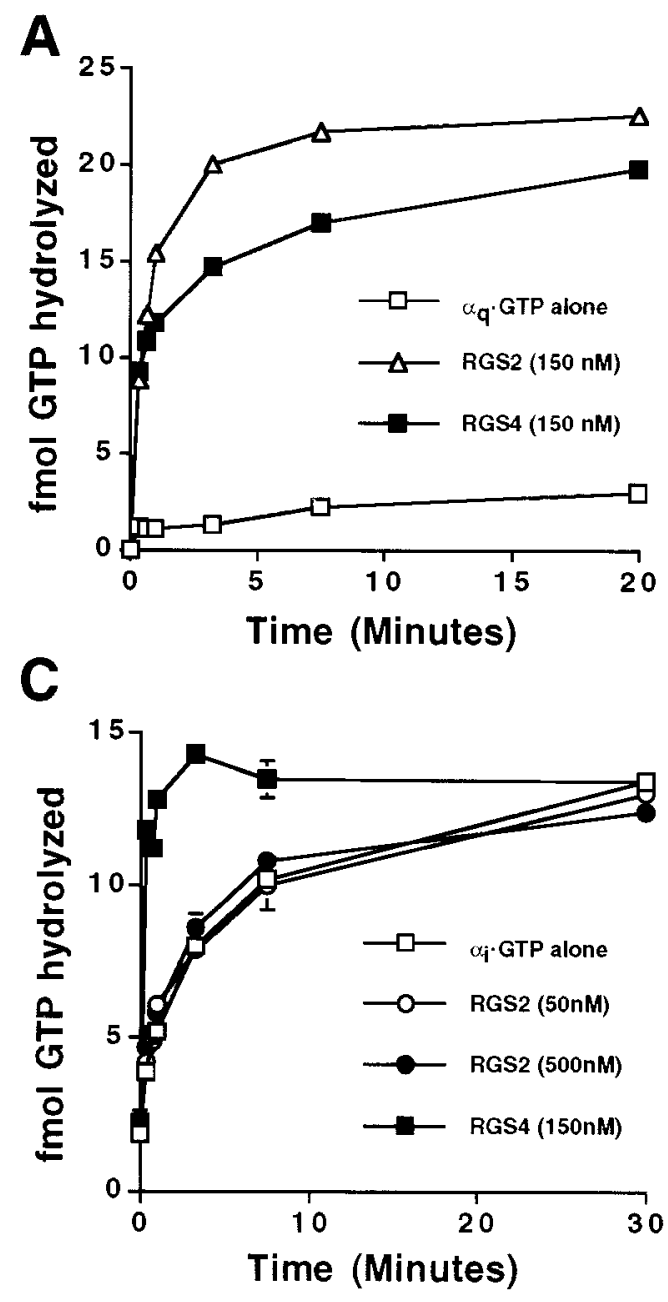

B

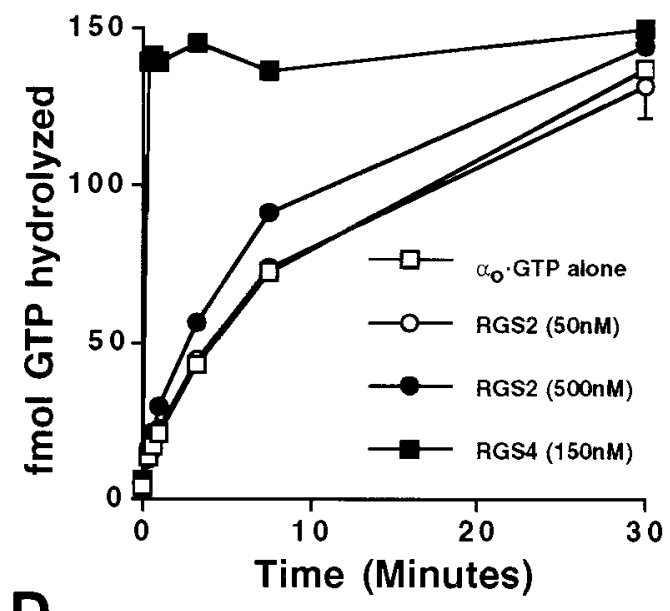

D
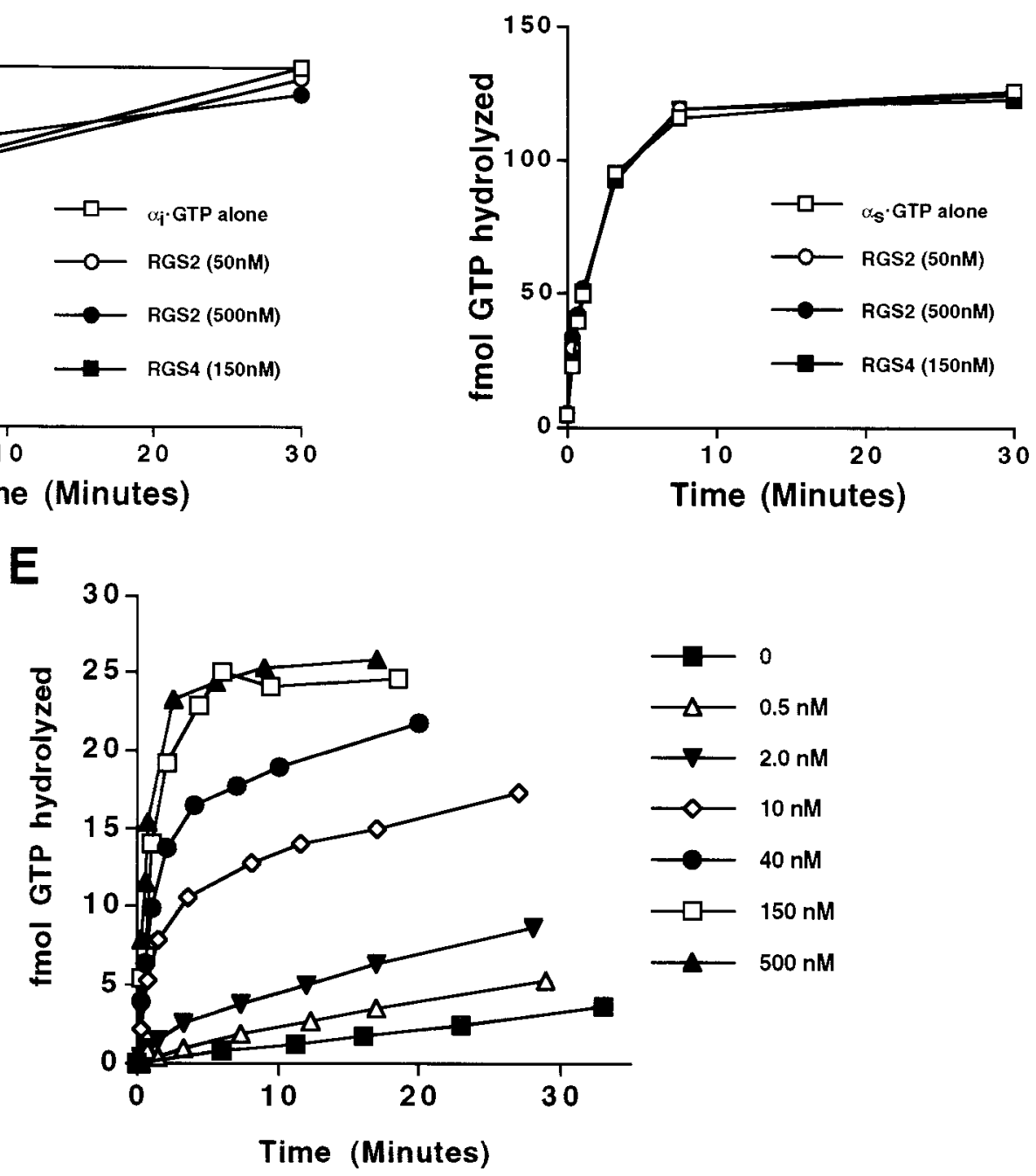

Figure 4. GAP activity of RGS2 for $\mathrm{G}_{\mathrm{q}} \cdot A-D$, Examination of in vitro GTPase activity of $0.2 \mathrm{~nm} \mathrm{R} 183 \mathrm{C} \mathrm{G}_{\mathrm{q}} \alpha(A), 0.85 \mathrm{~nm} \mathrm{G}_{\mathrm{o}} \alpha(B), 1.2 \mathrm{~nm} \mathrm{G}_{\mathrm{i}} \alpha 1(C)$, and $1.2 \mathrm{nM} \mathrm{G}_{\mathrm{s}} \alpha(D)$ in the presence of RGS2 and RGS4. GTPase activity was measured in the absence (open squares) or presence of purified RGS protein [RGS2, $50 \mathrm{~nm}$ (open circles), $150 \mathrm{~nm}$ (open triangles), or $500 \mathrm{nM}$ (filled circles); RGS4, $150 \mathrm{~nm}$ (filled squares) final concentration]. E, The effect of increasing RGS2 concentrations on the GTPase activity of $0.2 \mathrm{nM} \mathrm{R} 183 \mathrm{C} \mathrm{G}_{\mathrm{q}} \alpha$. The data for $\mathrm{G}_{\mathrm{s}} \alpha$ and $\mathrm{G}_{\mathrm{i}} \alpha$ are plotted as the average \pm SEM of duplicate measurements; the data for $\mathrm{G}_{\mathrm{q}} \alpha$ and $\mathrm{G}_{\mathrm{o}} \alpha$ are single points. The data are representative of four separate assays performed for each $\mathrm{G} \alpha$ protein. 


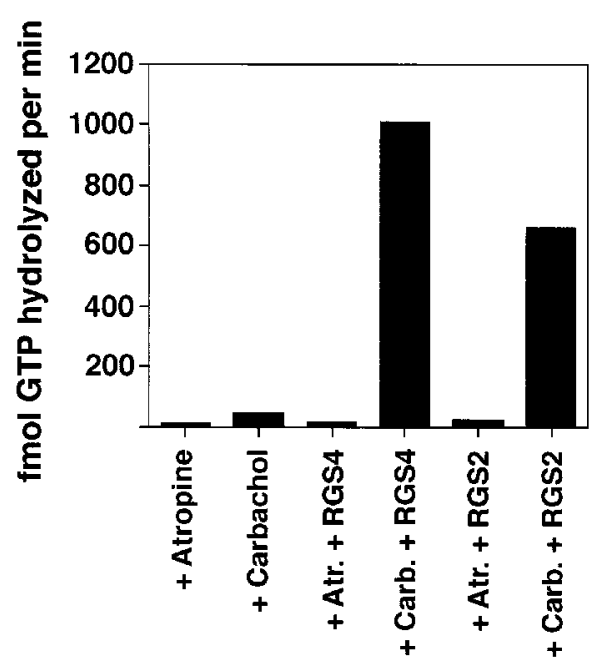

Figure 5. GAP activity of RGS2 with $\mathrm{M} 2 \mathrm{mAChR}\left(\mathrm{G}_{\mathrm{i}}\right)$ vesicles. $\mathrm{G}_{\mathrm{i}} 1$ were monitored in reconstituted vesicles containing the M2 mAChR and $G_{i}$ heterotrimer in the presence or absence of RGS2 or RGS4. The activation state of $\mathrm{G}_{\mathrm{i}}$ was controlled with the receptor agonist carbachol (1 mM) or the receptor antagonist atropine $(20 \mu \mathrm{M})$. The final concentrations of the proteins were $0.5 \mathrm{~nm} \mathrm{M} 2 \mathrm{mAChR}, 2 \mathrm{nM} \mathrm{G}_{\mathrm{i}}$, and $500 \mathrm{~nm}$ RGS2 or RGS4. The data are representative of two similar experiments.

cades consequent to receptor activation. One of the signaling events induced by several different G-proteins is the phosphorylation and activation of MAP kinase (Faure et al., 1994). The phosphorylation of MAP kinase leads to its translocation to the nucleus in which it phosphorylates several transcription factors that, in turn, control IEG expression (Xia et al., 1996). For our studies, we selected the M1 and M2 mAChRs, because they are well characterized and yield robust activation of $G_{q}$ and $G_{i}$, respectively, in heterologous expression systems (Wan et al., 1996). Furthermore, mAChRs are major excitatory receptors in the hippocampus and cerebral cortex and may therefore be the natural target of RGS2 in stimulated neurons. Both $\mathrm{G}_{\mathrm{q}^{-}}$and $\mathrm{G}_{\mathrm{i}}$-coupled receptors stimulate MAP kinase activation via distinct signaling pathways (Faure et al., 1994; Hawes et al., 1995). M2 mAChR $\left(\mathrm{G}_{\mathrm{i}}\right)$-mediated MAP kinase activation is believed to be transmitted through $\mathrm{G} \beta \gamma$ subunits, which is the same pathway used by yeast to mediate pheromone signaling. $\beta \gamma$ subunits activate MAP kinase through the sequential interaction of the signaling proteins phosphoinositide 3-kinase $\gamma$, tyrosine kinase, Shc, Grb2, Sos, Ras, and Raf (Della Rocca et al., 1997; Lopez-Ilasaca et al., 1997). In contrast, $\mathrm{G}_{\mathrm{q}} \alpha$ mediates $\mathrm{M} 1 \mathrm{mAChR}\left(\mathrm{G}_{\mathrm{q}}\right)$ stimulated MAP kinase activation by increasing phosphatidylinositol turnover (Hawes et al., 1995).

Initial experiments confirmed robust agonist-dependent activation of MAP kinase in COS cells that expressed M1 or M2 mAChRs (Fig. 6). COS cells were transiently transfected with combinations of mAChR and epitope-tagged MAP kinase (HAERK1). Transfected cells were exposed to the agonist carbachol for 5 min before immunoprecipitation of HA-ERK1, and HAMAP kinase activities were determined by the phosphorylation of MBP. Treatment of cells expressing M1 or M2 mAChR with carbachol caused a 20- or 40-fold increase in ERK1 kinase activity in these cells. Coexpression of RGS2 (or RGS4) inhibited both M1- and M2-dependent activation of MAP kinase. RGS2 inhibited M1-dependent activation of MAP kinase by $\sim 50 \%$ and inhibited M2-dependent activation of MAP kinase by $\sim 35 \%$. The similar activity of RGS2 for both M1- and M2-dependent MAP kinase activation is consistent with our observation that RGS2 can act as a GAP for both $\mathrm{G}_{\mathrm{q}} \alpha$ and $\mathrm{G}_{\mathrm{i}} \alpha$.

\section{DISCUSSION}

A central goal of neurobiology is to understand how neurons effect long-term changes in response to synaptic activity. In the present study, we demonstrate that RGS2 is a neuronal IEG and provide evidence for its contribution to cellular signaling. RGS2 gene expression is dynamically responsive to synaptic activity, as illustrated using the in vivo LTP paradigm. Induction in this paradigm is dependent on activation of NMDA receptors and is associated with long-term synaptic plasticity. RGS2 mRNA is also rapidly induced in the striatum by acute administration of haloperidol, suggesting regulation by dopamine-dependent mechanisms. The dynamic regulation of RGS2 appears to be unique among RGS family members that are expressed in brain. Although other members of the RGS family, including RGS4 and RGS7, are expressed in brain neurons and show extensive codistribution with RGS2 in cortex, amygdala, hippocampus, and striatum, they are not induced by MECS or haloperidol or in association with LTP. RGS2 is additionally notable because it functions as a GAP for both $\mathrm{G}_{\mathrm{i}}$ and $\mathrm{G}_{\mathrm{q}}$ in reconstituted lipid vesicles. These observations suggest that RGS2 induction may modify the signaling properties of stimulated neurons by reducing the magnitude or duration of $\mathrm{G}_{\mathrm{i}^{-}}$and $\mathrm{G}_{\mathrm{q}}$-dependent ligandreceptor systems. Our studies do not define which signaling systems are most affected by RGS2 upregulation; however, the major $\mathrm{G}_{\mathrm{q}}$-linked receptors of cortical and hippocampal granule cell neurons include M1 mAChRs, group I metabotropic glutamate receptors, $\alpha 1$ adrenergic receptors, bradykinin receptors, D2b dopamine receptors, and 5-HT2 serotonin receptors. Because these receptors are typically linked to phosphatidylinositol turnover, it is anticipated that RGS2 upregulation will modulate receptor-mediated release of intracellular calcium from inositoltrisphosphate-sensitive pools. This notion is supported by the recent report demonstrating that RGS4 inhibits calcium signaling by group I metabotropic glutamate receptors (Saugstad et al., 1998).

Our studies further demonstrate that RGS2 upregulation may impact signaling events leading to activation of MAP kinase. In cell assays, RGS2 shows inhibitory effects on both M1- and M2-dependent receptor activation of MAP kinase and is similar in efficacy to RGS4. This effect of RGS2 is consistent with its GAP activity for both $\mathrm{G}_{\mathrm{q}}$ and $\mathrm{G}_{\mathrm{i}}$. Because MAP kinase activation is linked to gene expression in neurons (Xia et al., 1996) and has been demonstrated to play an essential role in a model of activitydependent plasticity (Bailey et al., 1997; Kornhauser and Greenberg, 1997; Martin et al., 1997), upregulation of RGS2 may impact events at the nucleus, as well as the plasma membrane.

Members of the RGS family are rapidly upregulated in response to specific stimuli in other systems. SST2 is expressed at low constitutive levels in naive yeast and is transcriptionally induced by pheromone. Induction of SST2 is responsible for desensitization to pheromone signaling (Dietzel and Kurjan, 1987). Similarly, RGS1 expression is induced by a plateletactivating factor (PAF) in human B-cell lymphoma cell line, and elevated concentrations of RGS1 block PAF-induced MAP kinase activation (Druey et al., 1996). Furthermore, the level of EGL-10 activity quantitatively regulates the G-protein signaling in C. elegans (Koelle and Horvitz, 1996), suggesting that expression may be tightly controlled to regulate G-protein signaling. These examples, together with our present observations, support 
Figure 6. RGS2 and RGS4 inhibit mAChR-mediated MAP kinase activation. COS cells were transfected with an HA-tagged ERK1 plasmid, an M1 mAChR plasmid, or an M2 mAChR plasmid, in conjunction with empty vector or RGS expression plasmids. Transfected cells were exposed to carbachol $(100 \mu \mathrm{M})$ for $5 \mathrm{~min}$ before lysis and immunoprecipitation of HA-ERK1. The activity of HAMAP kinase (KINASE) was then assayed using $\mathrm{MBP}$ as the substrate. The radioactivity of MBP was determined by scintillation spectroscopy of excised bands and is presented as a percentage relative to the empty vector controls to $\mathrm{M} 2 \mathrm{mAChR}$ $\left(2.2 \times 10^{5} \mathrm{cpm}\right)$ or M1 mAChR $(5.0 \times$ $\left.10^{5} \mathrm{cpm}\right)$ controls. Note that RGS2 inhibited $\sim 70 \%$ of ERK activation by mAChR1 and $\sim 50 \%$ of activation by mAChR2. RGS4 produced similar levels of inhibition in these assays. Data are mean \pm range of duplicate determinations from a representative experiment. The same results were repeated in two to four independent experiments. Equivalent ERK1 (HA-ERK1) levels were detected in HA-immunoprecipitates by immunoblot $(W B)$ analysis.

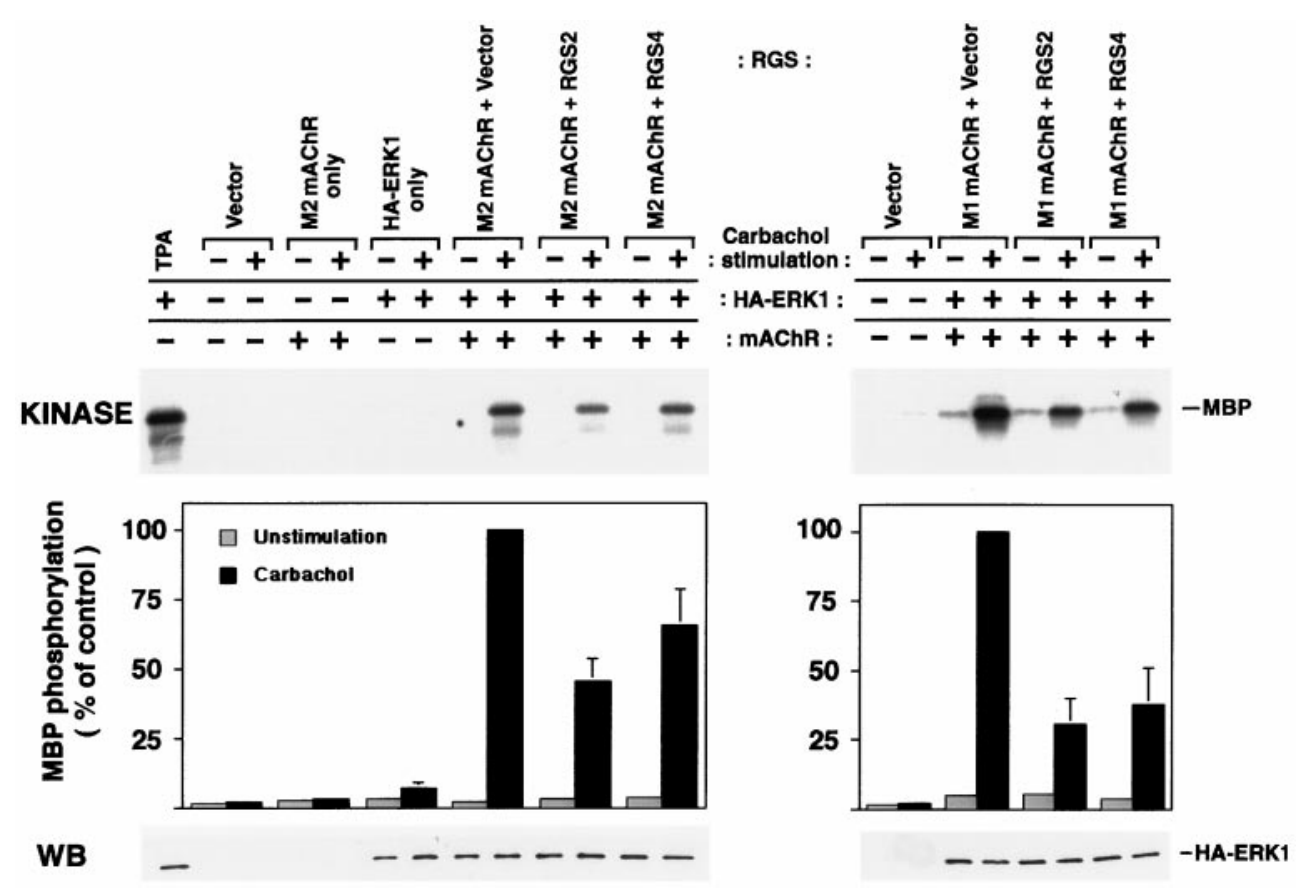

the notion that dynamic transcriptional control of specific RGS proteins may represent a general principle important in controlling the duration or intensity of G-protein-coupled receptor signaling.

EGL-10 is enriched in neuronal dendrites and is relatively excluded from the cell body or axon (Koelle and Horvitz, 1996). This subcellular targeting appears to be mediated by its N-terminal 120 amino acids (Koelle and Horvitz, 1996). This demonstration of subcellular targeting suggests that other RGS members may similarly be targeted to discrete subcellular regions. This may be important in understanding why multiple family members with shared G-protein specificity are coexpressed in neurons. Sequence comparisons indicate significant homology between the $\mathrm{N}$ terminus of EGL-10 and RGS7 (64\%) and RGS9 (33\%), whereas the $\mathrm{N}$ terminus of RGS4 shows similarity to RGS5 (67\%), RGS16 (55\%), and RGS14 (51\%). By contrast, the $\mathrm{N}$ terminus of RGS2 is not homologous to other RGS family members and may be hypothesized to confer unique targeting. We are not presently able to examine this issue because of the lack of specific immunoreagents. However, independent of a uniquely localized effect, upregulation of RGS2 might be anticipated to increase $\mathrm{G}_{\mathrm{s}}$ signaling because of the reciprocal relationship between $G_{i}$ and $G_{s}$. The late phase of hippocampal LTP is known to involve a persistent increase in protein kinase A activity (Frey et al., 1993) and to be dependent on protein synthesis (Frey and Morris, 1997). Upregulation of RGS2 might contribute to this phenomenon.

Biochemical characterization of the GAP activity of RGS2 revealed a paradox. All RGS proteins assayed previously have displayed GAP activity toward members of the $\mathrm{G}_{\mathrm{i}} \alpha$ subfamily of $\mathrm{G} \alpha$ proteins in solution. In contrast, demonstration of the GAP activity of RGS2 toward $\mathrm{G}_{\mathrm{i}} \alpha 1$ required reconstitution of the G-protein with receptors in phospholipid vesicles. We do not as yet understand the nature of this requirement. Reconstitution into vesicles may simply increase the effective concentrations of $\mathrm{G}_{\mathrm{i}} \alpha$ and RGS2. Other possibilities include a more specific requirement for phospholipid for the RGS-G-protein interaction or, perhaps, the formation of a complex of RGS2 and $\mathrm{G}_{\mathrm{i}} \alpha$ that includes receptor (Doupnik et al., 1997). A practical consequence of this result is to decrease substantially the significance of previous negative observations on RGS-G $\alpha$-protein interactions that were examined only in solution.

Dynamic regulation of RGS2 occurs in the context of other mechanisms that modulate G-protein-dependent signaling. Agonist-dependent phosphorylation of receptors by protein kinases and the subsequent binding of arrestin-like molecules contribute to signal desensitization (Freedman and Lefkowitz, 1996). This type of receptor phosphorylation appears to be involved in the rapid receptor trafficking processes that occur within minutes of agonist exposure. Another inhibitory mechanism involves downregulation of G-protein-coupled receptors, which may play a role in long-term desensitization of signaling (Hausdorff et al., 1990). In our studies of activity-regulated genes, we identified a novel IEG, termed Homer (Brakeman et al., 1997), which binds to the $\mathrm{C}$ terminus of group I metabotropic glutamate receptors. Group I metabotropic glutamate receptors are coupled to $\mathrm{G}_{\mathrm{q}}$ and function to release intracellular calcium pools. Thus, both RGS2 and Homer represent IEG responses to effect modulation of $\mathrm{G}_{\mathrm{q}}$-dependent signaling. The present study reinforces the important link between neuronal activity and long-term changes in cellular signaling and defines a novel mechanism in this process.

\section{REFERENCES}

Agranoff BW (1981) Learning and memory: biochemical approaches. Boston: Little, Brown.

Bailey CH, Kaang BK, Chen M, Martin KC, Lim CS, Casadio A, Kandel ER (1997) Mutation in the phosphorylation sites of MAP kinase blocks learning-related internalization of apCAM in Aplysia sensory neurons. Neuron 18:913-924.

Barnes CA, Jung MW, McNaughton BL, Korol DL, Andreasson K, Worley PF (1994) LTP saturation and spatial learning disruption: effects of task variables and saturation levels. J Neurosci 14:5793-5806.

Berman DM, Gilman AG (1998) Mammalian RGS protein: barbarians at the gate. J Biol Chem 273:1269-1272.

Berman DM, Wilkie TM, Gilman AG (1996) GAIP and RGS4 are 
GTPase-activating proteins for the Gi subfamily of $\mathrm{G}$ protein alpha subunits. Cell 86:445-452.

Bhat RV, Baraban JM (1993) Activation of transcription factor genes in striatum by cocaine: role of both serotonin and dopamine systems. J Pharmacol Exp Ther 267:496-505.

Biddlecome GH, Berstein G, Ross EM (1996) Regulation of phospholipase $\mathrm{C}$-beta1 by $\mathrm{Gq}$ and $\mathrm{m} 1$ muscarinic cholinergic receptor. Steadystate balance of receptor-mediated activation and GTPase-activating protein-promoted deactivation. J Biol Chem 271:7999-8007.

Brakeman PR, Lanahan AA, O'Brien R, Roche K, Barnes CA, Huganir RL, Worley PF (1997) Homer: a protein that selectively binds metabotropic glutamate receptors. Nature 386:284-288.

Carlson JH, Bergstrom DA, Walters JR (1986) Neurophysiological evidence that D-1 dopamine receptor blockade attenuates postsynaptic but not autoreceptor-mediated effects of dopamine agonists. Eur J Pharmacol 123:237-251.

Chan RK, Otte CA (1982a) Isolation and genetic analysis of Saccharomyces cerevisiae mutants supersensitive to G1 arrest by a factor and alpha factor pheromones. Mol Cell Biol 2:11-20.

Chan RK, Otte CA (1982b) Physiological characterization of Saccharomyces cerevisiae mutants supersensitive to G1 arrest by a factor and alpha factor pheromones. Mol Cell Biol 2:21-29.

Chatterjee TK, Eapen AK, Fisher RA (1997) A truncated form of RGS3 negatively regulates $G$ protein-coupled receptor stimulation of adenylyl cyclase and phosphoinositide phospholipase C. J Biol Chem 272:15481-15487.

Chen CK, Wieland T, Simon MI (1996) RGS-r, a retinal specific RGS protein, binds an intermediate conformation of transducin and enhances recycling. Proc Natl Acad Sci USA 93:12885-12889.

Cole AJ, Abu-Shakra S, Saffen DW, Baraban JM, Worley PF (1990) Rapid rise in transcription factor mRNAs in rat brain after electroshock-induced seizures. J Neurochem 55:1920-1927.

Della Rocca GJ, van Biesen T, Daaka Y, Luttrell DK, Luttrell LM, Lefkowitz RJ (1997) Ras-dependent mitogen-activated protein kinase activation by $\mathrm{G}$ protein-coupled receptors. Convergence of Gi- and Gq-mediated pathways on calcium/calmodulin, Pyk2: and Src kinase. J Biol Chem 272:19125-19132.

Dietzel C, Kurjan J (1987) Pheromonal regulation and sequence of the Saccharomyces cerevisiae SST2 gene: a model for desensitization to pheromone. Mol Cell Biol 7:4169-4177.

Dohlman HG, Thorner J (1997) RGS proteins and signaling by heterotrimeric G proteins. J Biol Chem 272:3871-3874.

Doupnik CA, Davidson N, Lester HA, Koufuji P (1997) RGS proteins reconstituted the rapid gating kinetics of $\mathrm{G} \beta \gamma$-activated inwardly rectifying $\mathrm{K}^{+}$channels. Proc Natl Acad Sci USA 94:10461-10466.

Dragunow M, Abraham WC, Goulding M, Mason SE, Robertson HA, Faull RL (1989) Long-term potentiation and the induction of c-fos mRNA and proteins in the dentate gyrus of unanesthetized rats. Neurosci Lett 101:274-280.

Druey KM, Blumer KJ, Kang VH, Kehrl JH (1996) Inhibition of G-protein-mediated MAP kinase activation by a new mammalian gene family. Nature 379:742-746.

Faure M, Voyno-Yasenetskaya TA, Bourne HR (1994) cAMP and beta gamma subunits of heterotrimeric $G$ proteins stimulate the mitogenactivated protein kinase pathway in COS-7 cells. J Biol Chem 269:7851-7854.

Flexner JB, Flexner LB, Stellar E (1963) Memory in mice as affected by intracerebral puromycin. Science 141:57-59.

Freedman NJ, Lefkowitz RJ (1996) Desensitization of G proteincoupled receptors. Recent Prog Horm Res 51:319-353.

Frey U, Huang YY, Kandel ER (1993) Effects of cAMP simulate a late stage of LTP in hippocampal CA1 neurons. Science 260:1661-1664.

Frey U, Morris RG (1997) Synaptic tagging and long-term potentiation. Nature 385:533-536.

Gilman AG (1987) G proteins: transducers of receptor-generated signals. Annu Rev Biochem 56:615-649.

Goelet P, Castellucci VF, Schacher S, Kandel ER (1986) The long and the short of long-term memory - a molecular framework. Nature 322:419-422.

Gold SJ, Ni YG, Dohlman HG, Nestler EJ (1997) Regulators of G-protein signaling (RGS) proteins: region-specific expression of nine subtypes in rat brain. J Neurosci 17:8024-8037.

Hamm HE, Gilchrist A (1996) Heterotrimeric G proteins. Curr Opin Cell Biol 8:189-196.

Hausdorff WP, Caron MG, Lefkowitz RJ (1990) Turning off the signal: desensitization of beta-adrenergic receptor function. FASEB J [Erratum (1990) 4:3049] 4:2881-2889.

Hawes BE, van Biesen T, Koch WJ, Luttrell LM, Lefkowitz RJ (1995) Distinct pathways of Gi- and Gq-mediated mitogen-activated protein kinase activation. J Biol Chem 270:17148-17153.

Hepler JR, Berman DM, Gilman AG, Kozasa T (1997) RGS4 and GAIP are GTPase-activating proteins for $\mathrm{Gq}$ alpha and block activation of phospholipase $\mathrm{C}$ beta by gamma-thio-GTP-Gq alpha. Proc Natl Acad Sci USA 94:428-432.

Heximer SP, Watson N, Linder ME, Blumer KJ, Hepler JR (1997) RGS2/G0S8 is a selective inhibitor of Gq $\alpha$ function. Proc Natl Acad Sci USA 94:14389-14393.

Huang C, Hepler JR, Gilman AG, Mumby SM (1997) Attenuation of Giand Gq-mediated signaling by expression of RGS4 or GAIP in mammalian cells. Proc Natl Acad Sci USA 94:6159-6163.

Hunt TW, Fields TA, Casey PJ, Peralta EG (1996) RGS10 is a selective activator of G alpha i GTPase activity. Nature 383:175-177.

Jeffery KJ, Abraham WC, Dragunow M, Mason SE (1990) Induction of Fos-like immunoreactivity and the maintenance of long-term potentiation in the dentate gyrus of unanesthetized rats. Brain Res Mol Brain Res 8:267-274.

Kandel ER (1991) Disorders of thought: schizophrenia. East Norwalk, CT: Appleton \& Lange.

Koelle MR (1997) A new family of G-protein regulators-the RGS proteins. Curr Opin Cell Biol 9:143-147.

Koelle MR, Horvitz HR (1996) EGL-10 regulates G protein signaling in the $C$. elegans nervous system and shares a conserved domain with many mammalian proteins. Cell 84:115-125.

Kornhauser JM, Greenberg ME (1997) A kinase to remember: dual roles for MAP kinase in long-term memory. Neuron 18:839-842.

Lalumiere M, Richardson CD (1995) Production of recombinant baculoviruses using rapid screening vectors that contain the gene for $\beta$-galactosidase. Totawa, NJ: Humana.

Lanahan A, Lyford G, Stevenson GS, Worley PF, Barnes CA (1997) Selective alteration of long-term potentiation-induced transcriptional response in hippocampus of aged, memory-impaired rats. J Neurosci 17:2876-2885.

Lee E, Linder ME, Gilman AG (1994) Expression of G-protein alpha subunits in Escherichia coli. Methods Enzymol 237:146-164.

Linder ME, Pang IH, Duronio RJ, Gordon JI, Sternweis PC, Gilman AG (1991) Lipid modifications of G protein subunits. Myristoylation of Go alpha increases its affinity for beta gamma. J Biol Chem 266:4654-4659.

Linzer DI, Nathans D (1983) Growth-related changes in specific mRNAs of cultured mouse cells. Proc Natl Acad Sci USA 80:4271-4275.

Lopez-Ilasaca M, Crespo P, Pellici PG, Gutkind JS, Wetzker R (1997) Linkage of $G$ protein-coupled receptors to the MAPK signaling pathway through PI 3-kinase gamma. Science 275:394-397.

Lyford GL, Yamagata K, Kaufmann WE, Barnes CA, Sanders LK, Copeland NG, Gilbert DJ, Jenkins NA, Lanahan AA, Worley PF (1995) Arc, a growth factor and activity-regulated gene, encodes a novel cytoskeleton-associated protein that is enriched in neuronal dendrites. Neuron 14:433-445.

Martin KC, Michael D, Rose JC, Barad M, Casadio A, Zhu H, Kandel ER (1997) MAP kinase translocates into the nucleus of the presynaptic cell and is required for long-term facilitation in Aplysia. Neuron 18:899-912.

McNaughton BL, Barnes CA, Rao G, Baldwin J, Rasmussen M (1986) Long-term enhancement of hippocampal synaptic transmission and the acquisition of spatial information. J Neurosci 6:563-571.

Morgan JI, Cohen DR, Hempstead JL, Curran T (1987) Mapping patterns of c-fos expression in the central nervous system after seizure. Science 237:192-197.

Neer EJ, Smith TF (1996) G protein heterodimers: new structures propel new questions. Cell 84:175-178.

Nguyen PV, Abel T, Kandel ER (1994) Requirement of a critical period of transcription for induction of a late phase of LTP. Science 265:1104-1107.

Parker EM, Kameyama K, Higashijima T, Ross EM (1991) Reconstitutively active $G$ protein-coupled receptors purified from baculovirusinfected insect cells. J Biol Chem 266:519-527.

Saffen DW, Cole AJ, Worley PF, Christy BA, Ryder K, Baraban JM (1988) Convulsant-induced increase in transcription factor messenger RNAs in rat brain. Proc Natl Acad Sci USA 85:7795-7799.

Saugstad JA, Marino MJ, Folk JA, Hepler JR, Conn PJ (1998) RGS4 
inhibits signaling by group I metabotropic glutamate receptors. J Neurosci 18:905-913.

Shatz CJ (1990) Impulse activity and the patterning of connections during CNS development. Neuron 5:745-756.

Siderovski DP, Hessel A, Chung S, Mak TW, Tyers M (1996) A new family of regulators of G-protein-coupled receptors? Curr Biol 6:211-212.

Siderovski DP, Heximer SP, Forsdyke DR (1994) A human gene encoding a putative basic helix-loop-helix phosphoprotein whose mRNA increases rapidly in cycloheximide-treated blood mononuclear cells. DNA Cell Biol 13:125-147.

Snow BE, Antonio L, Suggs S, Gutstein HB, Siderovski DP (1997) Molecular cloning and expression analysis of rat Rgs12 and Rgs14. Biochem Biophys Res Commun 233:770-777.

Wan Y, Kurosaki T, Huang XY (1996) Tyrosine kinases in activation of the MAP kinase cascade by G-protein-coupled receptors. Nature 380:541-544.

Watson N, Linder ME, Druey KM, Kehrl JH, Blumer KJ (1996) RGS family members: GTPase-activating proteins for heterotrimeric G-protein alpha-subunits. Nature 383:172-175.

Wong SK-F, Ross EM (1994) Chimeric muscarinic cholinergic: $\beta$-adrenergic receptors that are functionally promiscuous among $\mathrm{G}$ proteins. J Biol Chem 269:18968-18976.
Worley PF, Bhat RV, Baraban JM, Erickson CA, McNaughton BL, Barnes CA (1993) Thresholds for synaptic activation of transcription factors in hippocampus: correlation with long-term enhancement. J Neurosci 13:4776-4786.

Wu HK, Heng HH, Shi XM, Forsdyke DR, Tsui LC, Mak TW, Minden MD, Siderovski DP (1995) Differential expression of a basic helixloop-helix phosphoprotein gene, G0S8, in acute leukemia and localization to human chromosome 1q31. Leukemia 9:1291-1298.

Xia Z, Dudek H, Miranti CK, Greenberg ME (1996) Calcium influx via the NMDA receptor induces immediate early gene transcription by a MAP kinase/ERK-dependent mechanism. J Neurosci 16:5425-5436.

Yamagata K, Andreasson KI, Kaufmann WE, Barnes CA, Worley PF (1993) Expression of a mitogen-inducible cyclooxygenase in brain neurons: regulation by synaptic activity and glucocorticoids. Neuron 11:371-386

Yamagata K, Sanders LK, Kaufmann WE, Yee W, Barnes CA, Nathans D, Worley PF (1994) Rheb, a growth factor- and synaptic activityregulated gene, encodes a novel Ras-related protein. J Biol Chem 269:16333-16339.

Yan Y, Chi PP, Bourne HR (1997) RGS4 inhibits Gq-mediated activation of mitogen-activated protein kinase and phosphoinositide synthesis. J Biol Chem 272:11924-11927. 